\title{
Habermas, Modernity and Postmodernism; A Philosophical Inquiry
}

\author{
Fasil Merawi \\ College of Social Sciences and Humanities, Department of Governance, Post Box No: 395, \\ Wollega University, Nekemte, Ethiopia
}

\begin{tabular}{|c|c|}
\hline Abstract & Article Information \\
\hline \multirow{8}{*}{$\begin{array}{l}\text { The modern/postmodern debate is usually presented as one of universality vs. relativism, } \\
\text { rationalism vs. irrationalism and emancipation vs. deconstruction. This article tries to } \\
\text { critically expose and critique Habermas's discussion of postmodernism as a way of } \\
\text { highlighting some of the limitations of this lively discussion. This is to be accomplished } \\
\text { through a conceptual analysis of Habermas's defense of modernity against the } \\
\text { postmodernism of Jacques Derrida and Michel Foucault as elaborated in Habermas's } \\
\text { work The Philosophical Discourse of Modernity. Through such an analysis, I will argue for } \\
\text { the following points. (1) Habermas's discourse of modernity provides better accounts of } \\
\text { responsibility and emancipation compared to the postmodernism of Derrida and Foucault. } \\
\text { (2) Still, Habermas's discourse of modernity fails to fully address asymmetrical power } \\
\text { relations and (3) Habermas's modernity is Eurocentric in failing to fully deconstruct the } \\
\text { Eurocentric tendencies of the philosophical tradition of which it's a part. }\end{array}$} & Article History: \\
\hline & $\begin{array}{ll}\text { Received }: 20-07-2012 \\
\text { Revised } & : 27-09-2012 \\
\text { Accepted } & : 29-09-2012 \\
\end{array}$ \\
\hline & Keywords: \\
\hline & Modernity \\
\hline & Postmodernism \\
\hline & $\begin{array}{l}\text { Deconstruction } \\
\text { Disciplinary power }\end{array}$ \\
\hline & ${ }^{*}$ Corresponding Author: \\
\hline & $\begin{array}{l}\text { Fasil Merawi } \\
\text { E-mail: } \\
\text { mynameisfas@yahoo.com }\end{array}$ \\
\hline
\end{tabular}

\section{INTRODUCTION}

The modern/postmodern debate possesses an interdisciplinary significance. This is predicated on the assumption that modern forms of knowledge, both in the social and natural sciences are the logical outcome of modernity's attempt to evolve its own normative criteria of truth and thereby detach itself from the premodern world of tradition and authority. Thus the modern/postmodern debate is a matter of deciding whether modern society's conception of history, universal progress and the enlightened self should be preserved, or there is a need to herald a postmodern age where the repressive and absolutist facets of modernity are left behind for a diversified and fragmented approach that's critical towards accepted realities. In this debate the German philosopher Jürgen Habermas emerges as a strong defender of the values of Enlightenment and modernity, whereas Jacques Derrida and Michel Foucault are categorized under the postmodernist approach which is critical towards modern progress, modern knowledge and generally modern society.
What permeates all works of Habermas is an attempt to reformulate and critically appropriate the values of modernity and the Enlightenment as a way of both diagnosing and providing a remedy for today's society's problems. In this process, Habermas becomes highly critical towards postmodernism which he conceives as a farewell to modern society's emancipatory potentials embedded in everyday communication.

The essay starts by discussing Habermas's attempt to situate modernity as a project in terms of its difference from modernism, modernization and postmodernism. Section two constitutes a critical exposition of Habermas's views on postmodernism. Here, I will particularly focus on Habermas's discussion of Derrida and Foucault in The Philosophical Discourse of Modernity. Finally in section three I try to introduce my own individual insights into the debate through identifying the positive and negative aspects of Habermas's discussion of postmodernism. 


\section{MATERIALS AND METHODS}

Methodologically, the research is based on qualitative approaches depending up on the literature review of secondary sources like books, documents and Journals related to the topic.

\section{Modernity, Modernism, Modernization and Postmodernism}

Habermas's way of comprehending the issue of modernity is to situate it in terms of other concepts like modernization, modernism and postmodernism. Generally the concept of modernity is usually crystallized around the development of rationality in the modern European period which is supposedly individualistic, reflective, and multidimensional in trying to question every aspect of our lives. For Habermas, modernity is a realization of communicative rationality which makes explicit the implicit communicative potential of modern societies. Thus modernity differs from modernization, which broadly refers to how rationality was interpreted in science and technology signifying material achievements in the modern period. Today, as Habermas sees it, Weber's rationalization appears under a theme of 'modernization'. Accordingly, modernization supposedly consists of various ideals affirming others which are related to ideas like increase in accumulated wealth, productivity, mobilization of resources, emergence of central administration, urbanization, secularization, increase in rights and participation in government, and so on. Habermas contends that the theory of modernization changes Weber's occidental rationalization and abandonment of religious world-views in two senses. On the one hand, seeing modernity as a universal model and criteria against which developments of societies will be assessed. On the other, abandoning accounts of the rationalization of the life world so that modernity and rationality will be uncoupled (Habermas, 1987).

Habermas also insisted in distinguishing modernity from modernism which criticizes the exaggerated and destructive facets of modern rationality and instead tries to bring the aesthetic dimension into focus. In The Philosophical Discourse of Modernity, Habermas clearly states that he is trying to discuss modernity from a philosophical and not an aesthetic angle. Here, he distinguishes modernity from modernism, which is a certain movement in art and literature that could be seen as a critique of modernity. Modernism amongst other things advocated new and unusual ideas in art and literature, new conceptions of time, limitations of modern culture, exaggerated rationality, ills of capitalism, urban life and so on. Habermas claims that historically; "the mentality of aesthetic modernity begins to take shape clearly with Baudelaire and with his theory of art, influenced as it was by Edgar Allan Poe. It then unfolded in the avant garde artistic movements and finally attained its zenith with surrealism and the Dadaists of the cafe Voltaire" (Benhabib, 1997).

Finally Habermas's modernity stands contrarily to postmodernism which envisages an abandonment of modern rationality in favor of a heterogeneous, diverse approach that addresses the complexity of human life. For Habermas, one could identify two facets of postmodernism. A 'neoconservative' one, which doubts the process of rationalization that is said to have taken place in the West and also, an 'anarchist' one which admits that modernity is rationalization but asserts that reason with the collapse of modernity is manifesting itself as repressive and instrumental (Habermas, 1987). Thus, modernity could be seen in how it defends an emancipatory ideal of rationality which differs from modernization, modernism and postmodernism.

Habermas's discourse of modernity heavily draws on the sociology of Max Weber and Hegel's philosophical insights o the modern age as a way of situating the issue of modernity. Habermas appropriates Weber's notion of rationalization or the process through which a secular culture emerged in the modern West, coupled with the Hegelian notion that it's the principle of freedom or subjectivity that best expresses the spirit of the modern age. Habermas begins his characterization of modernity by a discussion of the rationalization of the life world found in Weber's sociology of religion. Thus for Habermas, Weber "designates as rationalization every expansion of empirical knowledge, of predictive capacity, of instrumental and organizational mastery of empirical processes" (Habermas, 1984). In his sociology of religion, Max Weber talks of how the abandonment and distancing from religious accounts led to a process of rationalization in the West. Accordingly, the abandoning of the religious world views goes along with the emergence of three 'value-spheres' manifesting a secular outlook. There emerged theoretical, practical and aesthetic spheres (Habermas, 1987). This for Habermas is a process involving examination of one's own cultural background, emergence of universal norms and values, the rise of a communicative rationality and how the individual identities emerge in this process. 


\section{Fasil Merawi}

Following the famous German historian Reinhart Koselleck, Habermas asserts that terms like modern, modernity and modernization have in them an idea of striving for a future potential, progress and actualization. Especially during Hegel, history comes to be conceived as a continuous process moving towards progress. Radical and revolutionary concepts emerged in the eighteenth century in general and Hegelian philosophy in particular, that are supposed to be manifestations of the novel and unique age. Hence, "words such as revolution, progress, emancipation, development, crisis and zeitgeist" (Habermas, 1987) emerged signifying the radical nature of the present. According to Hegel, the essence of the modern age lies in its principle of 'subjectivity'. This principle can be further divided into the ideals of individualism, right to criticism, autonomy and idealism. Rather than appealing to any tradition, or higher authority, the individual was seen as the proper subject and starting point of reflection. This was related to criticism and the fact that nothing was to be exempted from critical examination. This in turn, implies autonomy or freedom of humans, or the individual, to reflect on the modern condition. Finally reason was conceived as the tool of this world that's to be utilized for interrogation, aiming at the truth (Habermas, 1987). This principle of subjectivity for Hegel was established through key historical movements like the Reformation, the Enlightenment and French revolution.

The significance of the reformation lies in its focus on the primacy of the individual and how he or she independently relates to God rather than the authority of Bible, the church or religious figures. Enlightenment further asserted the supremacy of reason by advocating reason's ability to provide solutions for our social, political, economic, artistic and generally all aspects of our lives. Further, in the French revolution, the status of traditional laws and the state were eroded as a result of the assertion of individual freedom and liberty. As a result of this, modern forms of inquiries and generally modern life came to be organized around the principle of subjectivity. First of all, the natural sciences rejected any super natural explanations and in turn focused on the idea of a reflecting subject knowing nature that's already available as a raw data. Also in morality, moral concepts originated from reason and human authority, and the freedom of individual members designating what's right and wrong, and inconsistent with the common good. In art, especially Romanticism, the individual and its inward experiences were emphasized.
Sci. Technol. Arts Res. J., July-Sep 2012, 1(3): 75-87

In philosophy, the principle of subjectivity was established in Descartes cogito; where there is a mind-body dualism and the thinking ' $l$ ' is the starting point of reflection. It reached its highest stage, in Kant and the division of reason into three spheres and hence the further articulation of subjectivity. Kant, in his critique of pure reason, tries to put an end to the dilemmas of the metaphysical tradition and its exaggerated reason by limiting knowledge to things as they appear to us, and in turn dividing this possible cognition into three spheres, and putting the subject as starting point of reflection. Hence; "by the end of the eighteenth century, science, morality and art were even institutionally differentiated as realms of activity in which questions of truth, of justice, and of taste were autonomously elaborated, that is, each under its own specific aspect of validity." (Habermas, 1987) Here, what interests Habermas, is to what extent modernity has managed to detach itself from pre-modern times, from where it borrows its criteria of truth, right and wrong and generally truth. Habermas also asks, to what extent does the past affect the 'modern' not just the present but the novel present? Here Habermas claimed in his radical thesis on modernity that: "Modernity can and will no longer borrow the criteria by which it takes its orientation from the models supplied by another epoch; it has to create its normativity out of itself." (ibid)

Habermas here is claiming that because of the rationalization of the life world, and distancing from religious world views, three value spheres arise i.e. that of theoretical, practical and aesthetic. Thus for Habermas, "modern structures of consciousness emerged from the universal- historical process of worldview rationalization, that is from the disenchantment of religious-metaphysical worldviews"(Habermas, 1984). These spheres are related to the life world and its validity claims in everyday communicative processes relating to the objective, social and subjective worlds. What this implies, is that it is from the raising and contestation of different validity claims that modernity infers its criteria of good, bad and generally truth. So, modernity has succeeded in creating its own criteria's and tools for arriving at the truth.

Habermas tries to locate the 'unpursued' path in modern rationality, which is communicative reason. This is a reason fuelled by the rationalization of the life world in relation to premodern grounds of tradition and authority. Habermas's rationality is based on the day to day communicative practices of modern societies, their standard speech acts and the distinct claims 


\section{Fasil Merawi}

raised in relation to the objective, social and subjective dimensions of reality. The essence of communicative rationality lies in how language coordinates actions; how actors in an intersubjective communicative process tend to respect some rules and in the process how understanding is to be achieved. In the communicative paradigm, when a speech act is forwarded, the one to which it's directed, recognizes it and thereby offers a reply establishing an intersubjective communicative process. What makes this communicative process possible are the shared backgrounds of meanings and idealizing presuppositions that guide communicative processes, and also the fact that those in communication are, oriented towards consensus. Thus in Habermas, "by combining the theories of communicative action and social evolution a theory of modernity is generated that is intended to explain the specific rationalization processes of modernity" (Owen, 2002).

In Habermas's communicative rationality, the life world is what integrates the individuals as a whole by forming a common meaning. It's the context in which individuals dwell and affirm their uniqueness by presenting their claims. The life world is to be deciphered through everyday communicative action, but by itself, its "always only 'co-given' and has to evade thematization" (Habermas, 1987).One could easily look at speech acts and validity claims, and identify an intersubjectively communicative process, but the life world on the contrary, is what lies behind everyday communication, supplying materials to be reflected upon and a shared meaning that ties individuals and brings them into a communicative arena.

In pre-modern forms of life, tradition and authority were what dictated the everyday world and the life world. On the move from pre-modern to modern forms of life, generally in "cultural level" the basic traditionally conservative concepts that lay at the ground of the horizon begun to shift into concepts to be reflected upon, principles to be argued upon the "societal level". Thus, new general roles and universal moral insights began to emerge out of those particular roles based on religion, authority and myth. Finally "on the level of personality" the cognitive structures acquired in the process of socialization are dissociated ever more emphatically from the contents of cultural knowledge with which they were initially integrated in "concrete thinking" (Habermas, 1987).
Sci. Technol. Arts Res. J., July-Sep 2012, 1(3): 75-87

Habermas claims that his theory of communicative action is one that entertains a mutual relation between everyday world and the life world, instead of one being subsumed into the other. As Finlayson puts it; "The life world has several functions. It provides the context for action... on the one hand; it is a force for social integration. At the very same time the platform of agreement that the life world provides is the condition of the possibility of critical reflection and possible disagreement." (Finlayson, 2005, 52-53) Habermas admits that especially with the advent of capitalism, the life world and everyday communicative action are more and more threatened by the instrumental rationality of state and economy. This is what he calls the colonization of the life world. But what is the colonization of the life world?

to begin with the steering media of money and power became uncoupled from the life world. As the net works of instrumental action increase in their density and complicity so they gradually intrude into the life world and absorb its functions. As the domain of the life world shrinks a whole gamut of what Habermas calls' social pathologies arise (Finlayson, 2005).

Still, whereas the radical critics equate, in some cases, reasoning with repression, and in others, call for the renewal of archaic, heterogeneous forces out of the bounds of the modern, Habermas sees the only alternative as one of strengthening the life world and everyday communicative action as the locus of critical reflection and hence grounds for the emergence of a critical social theory of society.

\section{Habermas and Postmodernism}

What motivated Habermas's discussion of the philosophical discourse of modernity is the postmodernist movement as it grew out of what was referred to as the poststructuralism of especially Foucault and Derrida. Habermas basically tries to preserve and reformulate the values of the Enlightenment and the modern process of rationalization in general, by strengthening the communicative rationality which is implicitly being practiced in the day to day lives of modern societies. Along these lines, Habermas developed a critique of the postmodernist movements of Derrida and Foucault in particular. Still, what is postmodernism, and why does Habermas view it as a threat to Modernity, Enlightenment and communicative rationality? 


\section{Fasil Merawi}

The word postmodern is usually employed to specify intellectual positions which in one way or another tried or managed to degrade/undermine the assumptions which lie at the core of Western civilization especially modern society. Thus, the postmodernist venture exposed and severely criticized capitalism, globalization, anthropocentrism and metaphysical speculation amongst others. As Walter Truett Anderson sees it, Postmodernism " to some, it means funny architecture, to others, French intellectuals you can't understand; to still others, anything weird, campy, trendy or high tech. Some people equate it with the idea that all values and beliefs are equal" (Anderson, 1995). As Anderson sees it, besides tracing the emergence of the postmodern historically, one way of addressing the postmodern issue, is focusing on distinguishing between 'postmodernity' and 'postmodernism'. 'Postmodernity' constitutes the state in which our basic values, 'grand narrative', metaphysical systems, historiography, and our lives in general are currently being questioned. In this context, 'Postmodernism' relates to the various theoretical formulations trying to articulated this chaotic and fragmented situation, and trying to translate it and make it part of their theoretical explications and critiques. (Anderson, 1995) Thus alongside these lines Steven Best argued that " the prefix 'post' is ambiguous to the extent that it has temporal and philosophical meanings, signifying both a movement after and rejection of modern movements in theory and the arts" (Best, 2005).

Jean Francois Lyotard's The postmodern condition, a report on knowledge; is usually taken as a pioneering work in terms of introducing the term postmodernism in philosophical circles. Lyotard pictured the postmodern condition as one in which uniform conceptions of history; universalistic ideals of science and knowledge, religious narratives, metaphysical stories have lost their capacities to stand as adequate guidelines for our lives. This in turn has led to the emergence of different narratives, stories and guidelines.

As Lawrence Cahoone, in his from modernism to postmodernism, an anthology sees it; there are certain traits that unify the postmodernists. These include, dynamism in terms of signs, abandoning the search for origins and focusing on frameworks of construction and interpretation. Further, postmodernists usually argue that "knowledge is something humanly made" coupled with the contextualization of values and norms and critique of exploitative, 'repressive' forms of rationality. Finally most postmodernists employ a "notorious difficult writing style" (Cahoone, 2003).
Sci. Technol. Arts Res. J., July-Sep 2012, 1(3): 75-87

For Richard Rorty, one way of recasting, the modern/postmodern debate is to situate it in terms of the Habermas/Lyotard controversy. While Habermas working within Kant ,Hegel and Weber's views, focuses on the development of three value spheres, the emergence of a distinct consciousness of time, and rationalization of the life world; Lyotard, on the other hand, describes the downfall of 'grand narratives' and overarching, all encompassing forms of speculations. Lyotard for Habermas leaves the scene with no basis for critique, while Habermas for Lyotard presents nothing but another 'grand Narrative' in his communicative rationality (Rorty, 1984). In the following sections, we are going to look at Habermas's critique of Derrida and Foucault's analysis of modernity.

\section{Deconstruction Versus Communicative Rationality}

In developing a position that tries to reform Western modernity, Habermas came up with a communicative rationality that excavates reason as a communicative tool and is critical of the different dimensions of life, and thereby furthers the project of modernity. In his work, The Philosophical Discourse of Modernity Habermas tries to show where the critics of modernity have been misguided. He shows that their misunderstandings are largely situated within the assumptions of the paradigm of consciousness or philosophy of the subject. In the philosophy of the subject, the focus is on the autonomous ego which is used to build grand systems and theories. As an alternative, Habermas tires to conceive knowledge, rationality and truth generally in terms of the participation of free individuals in a communicative process, where empirically testable and disputable claims are to be raised. In this regard, Habermas appealed to universal pragmatics which purports to articulate the universal and unavoidable presuppositions that are operative in the successful employment of speech acts oriented to achieving mutual understanding. Thus universal pragmatics "as a reconstructive science, investigates the 'universal and unavoidable presuppositions', that are operative in the successful employment of speech acts oriented to achieving mutual understanding" (Badillo, 1991).

As Habermas sees it, one of the followers of Nietzsche's idea that, philosophical discourses are not about logic and argumentation, but employment of the better rhetoric against lesser ones, is Jacques Derrida. One could see how Derrida's general project of deconstruction stands against Habermas's communicative rationality in two senses. First Derrida negates communicative 


\section{Fasil Merawi}

rationality and the three validity claims by emphasizing the infinite referral of meaning and showing that everyday communication is affected by abnormal, poetic and artistic uses of language. Secondly, he undermines Habermas's understanding of the specialized forms of inquiry, and specifically the status of philosophical discourse, by arguing that, there is no distinction between logic and rhetoric, and that all texts can be analyzed in literary-rhetorical terms.

Habermas's discussion of Derrida starts by pointing out the relation between Derrida's 'deconstruction' and Heidegger's 'destruction' of the western metaphysical tradition. Accordingly, both Heidegger and Derrida, tried to make a general analysis of the philosophical tradition with an aim of trying to show the limitations and the extent to which the metaphysical tradition can be justified. For Heidegger, analysis of the whole meant looking at history of metaphysics, exposing its 'forgetfulness' of Being, and trying to establish a new analysis in the Dasein Analytic. In Derrida, what we have is a criticism of the whole metaphysical tradition as trying to base itself in an absolute, certain, truth that is to be expressed in speech and serves as a foundation for all discussions. So, deconstruction, takes a form of destructing the history of philosophy by exposing its foundations, criticizing its dichotomies and finally emphasizing an intrinsic relation between the different oppositions and show how meaning is produced through these relations. Thus Habermas claims that there is an affinity between Heidegger's destruction and Derrida's Deconstruction (Habermas, 1987). Even though, Derrida followed Heidegger in making an analysis of the whole metaphysical tradition and arguing for its exposure, still he was against the kind of views Heidegger developed on his later years towards Being, language and truth.

So, why did Heidegger turn to language? In his Dasein Analytic, Heidegger tried to construct the structures that made possible Dasein's visibility and day to day life. But, later, Heidegger bestowed to language a status of revealing the status of an absolute truth i.e. the truth of Being. As, Habermas puts it, Derrida was against Heidegger's tendency to see language as starting with a truth of Being. This "metaphorics of proximity, of simple and immediate presence" is what Derrida rejects, according to Habermas. Here we can ask, to what does Derrida refers to by the metaphysical tradition. For, Derrida, metaphysics is mainly characterized by two main assumptions. Looking for an absolute and certain ground to base our discussions of truth, morality,
Sci. Technol. Arts Res. J., July-Sep 2012, 1(3): 75-87

reality, knowledge, values and so on; and also a binary, oppositional way of thinking, where one part of the dichotomy is said to be inferior to the other (Ryan, 1982). So, has Heidegger succumbed to the metaphysical tradition? For Derrida, First, even though there is distinction between Being and beings in Heidegger, still the focus is on forgetfulness of Being. The whole tradition has been focused on contemplating beings and entities for Heidegger. Instead he tries to address the concealed issue of being as such. Dasein is only significant in so far as it is able to address this ultimate forgetfulness. Also, Heidegger's insistence on grounding everything on an ultimate reality is seen in his later views on language where beings are not active producers of truth but only channels through which the truth of Being is manifested in the language they speak. Habermas is also against Heidegger's understanding of language, because this kind of analysis is against his idea that, truth is to be found in the three validity claims and the ability of participants in an intersubjective communication to convince each other through the raising and defending of these claims. This is because, in Heidegger, truth is not something we produce, but simply a manifestation of a higher reality.

Acknowledging the limitations of Heidegger's analysis, Derrida according to Habermas, turned his face to an analysis of language inspired by structuralism. Derrida took from structuralism its insistence on analyzing meaning not based on some external, absolute, metaphysical criteria but simply by looking at how meaning is produced in relation to a system of signs. Thus Derrida asserts " as modern structural thought has clearly realized, language is a system of signs and linguistics is part and parcel of the science of signs" ( Derrida, 1997). Still, the Structuralist ideal of trying to come up with objective structures that can be used to analyze day to day language was rejected by Derrida. Instead, Derrida's attempt was to expose the foundations of language as being metaphysical in their Nature (Habermas, 1987). Still, how could one criticize metaphysics by criticizing language?

As we saw earlier, one of the ways through which Derrida characterized metaphysics, is in terms of thinking in dichotomies of superiority and inferiority. Here Derrida focused on the speech/writing binary, where speech is favored. Derrida wanted to apply his Deconstruction against this Binary. But, first what is deconstruction? Deconstruction is an attempt to expose the nature of texts, and according to some, it takes the form of exposing binaries, reversing the relation between the binaries, and 


\section{Fasil Merawi}

finally showing that the two components of the binaries are not inferior or superior to one another but are simply interdependent, since meaning is produced by them excluding and differing from one another. Alongside these lines the 'logocentric' tendency of the metaphysical tradition focuses on the search for something absolute clear and self-evident, while it's 'Phonocentrism' emphasizes how speech is able to convey this i.e. the highest truth, more than writing. Hence "To this degree, Phonocentrism and logocentrism are akin to one another" (Habermas, 1987). In of Grammatology Derrida writes, "phonocentrism merges with the historical determination of the meaning of being in general as presence" (Derrida, 1997).

One of the dichotomies of superiority and inferiority that Derrida focuses on is that of logic and rhetoric, and he wants to question and reverse the relation. Habermas sees this, as Derrida's attempt to avoid self-referentiality in the critique of reason. This is to be accomplished by abolishing any distinction between philosophy and literature and trying to bring logic and argumentative reason under a general analysis of text and literature by way of deconstruction. Martin J. Matustik, saw Habermas's idea of performative contradiction as, something;

\section{Concretely defined within its existential context, an argument that attacks all rational argumentation, that reasons against reason as such, that wholly blackmails any claim to truth, that concludes in a rejection of normative Judgments that sincerely undermines the possibility of authenticity in discourse, is in contradiction with its own performance (Matustik, 1989).}

Derrida tried to appropriate Nietzsche's idea that philosophical texts are not mainly about arguments but employment of the better rhetoric against the lesser ones (Habermas, 1987). Here what Derrida's deconstruction tries to do is show that philosophical texts could be analyzed in literary terms just like every other text. Here, what we have is exposition of the different binaries in the text, which shows how contradictory claims are present, and the analysis of rhetorical meanings lead to affirmation of relations of difference. Hence, Derrida, according to Habermas is claiming that: "[b]lindness and insight are rhetorically interwoven with one another" (Habermas, 1987). In most so called philosophical texts, there is a tendency to focus just on the logic and arguments. What Derrida is claiming is that the rhetoric, strategies, metaphors, hidden agendas also need to be
Sci. Technol. Arts Res. J., July-Sep 2012, 1(3): 75-87

emphasized. So the recognition of elements other than logic will lead to a general analysis of texts with an aim of exposing their biases inscribed in their binaries and how both elements of rhetoric and argumentation are to be found on texts in general. Habermas asserts that the truth of Derrida's deconstructive venture is based on three assumptions which are intrinsically related with one another.

1. Literary criticism is not primarily a scientific (or scholarly: ..) enterprise but observes the same rhetorical criteria as its literary objects.

2. Far from there being a genre distinction between philosophy and literature, philosophical texts can be rendered accessible in their essential contexts by literary criticism.

3. The primacy of rhetoric over logic means the overall responsibility of rhetoric for the general qualities of an all embracing context of text, within which all genre distinctions are ultimately dissolved (Habermas, 1987).

As we can see from these three points, criticism is seen not in terms of objective validly and value free assumptions but of an artistic and literary nature in general. There is no clear demarcation between works of literature and philosophy. Thus, all works including philosophy should be categorized under literature and literary criticism should be the proper way of interrogating texts. Finally, since rhetoric is present in every discourse and forms of inquiry, then the idea of science and philosophy as something objective, certain, valid, free of rhetoric, as employing experiment and logic, against personal values and rhetoric is to be questioned. Derrida maintains "Criticism, if it is called upon to enter into explication and exchange With literary writing, someday will not have to wait for this resistance first to be organized into a 'philosophy' which would govern some methodology of aesthetics whose principles criticism would receive. For philosophy, during its history has been determined as the reflection of poetic inauguration" (Derrida, 2005).

In deploying literary criticism, what Derrida's deconstruction tries to do is, question the socalled logical consistency and validity of philosophy and science, and show that in both everyday communication and special forms of inquiry, rhetorical elements are found intertwined with different arguments and propositions. Accordingly, literary criticism in deconstruction is 


\section{Fasil Merawi}

not about applying a scientific method, in the sense of validity, objectivity, and so on. Literary criticism questions ideas of autonomous forms of inquiries, (for instance of art), and tries to show the interplay of different elements, logical and rhetorical in a given discourse. Generally it has a task of criticizing the metaphysical tradition's search for absolute origins and final foundations, the prioritizing of speech over writing and so on (Habermas, 1987). What all this implies is that, literary criticism is not something that tries to contemplate the secondary, artistic, imaginative use of language.

As Habermas sees it, in Derrida, literary criticism becomes the highest form of criticism, evaluating the nature of texts, exposing their tensions, hidden strategies and showing the existence of different forms of justification. Accordingly, If, philosophical texts are to be analyzed just like every other text through literary criticism, or the kind of criticisms relating to works of literature, then the critique of metaphysics becomes analogous to critique of literature, since critique of metaphysics falls under philosophical criticism. This is a way of subsuming philosophy under literature. Habermas, using Jonathan Culler, further argues that, this implies that literature, gains the status of philosophy, if literary criticism is employed as a critique of metaphysics (Habermas, 1987).

As Habermas sees it, as long as participants in an intersubjectivist communicative process are oriented towards understanding, then meaning will not be deferred. Abnormal interpretations and usages of language could be simply identified as something that hinders consensus and understanding. Idealizations that are found beyond communicative action and the fact that the various claims raised during communication are open to critique, and can be empirically tested will easily help to "distinguish between 'usual' and 'parasitic' uses of language" (Habermas, 1987). By 'parasitic', Habermas develops his idea that the normal use of language in everyday communication is for reaching understanding. Other artistic, metaphorical and non-literal usages of language are derived from the normal usage. Further, even though 'parasitic' usages of language prevail in everyday communication; still actors are able to bypass these usages since they are oriented towards reaching understanding.

Derrida is accused by Habermas of failing to distinguish between how language has a capacity of making the world visible and intelligible and how it can be used to solve specific problems.
Sci. Technol. Arts Res. J., July-Sep 2012, 1(3): 75-87

So, Derrida in his general notion of a 'text' tried to merge all the sciences, including philosophy, criticism, art, literature and so on under the category of literature. Habermas claims that on the one hand, we have everyday world of communication based in the different validity claims, while on the other, the various specialized forms of inquiry that are geared at solving specific problems. Philosophy and literary criticism are found between the two.

Literary criticism connects everyday world and the artistic realm, while philosophy, is related to the forms of inquiries in having a universalistic dimension. Philosophy facilitates disputation of claims between everyday world and specialized inquiries (Habermas, 1987). Habermas admits that rhetorical and poetic elements are found in every discourse. Still they are marginalized and only become dominant in poetic discourse. So, such rhetorical and artistic elements don't have an effect in the claims and methods of the various forms of inquiries. Accordingly, in both everyday communication and the specific forms of inquiry the rhetorical elements can be found but are marginalized. What about in philosophy and literary criticism? Philosophy and literary criticism play the role of presenting the claims and findings of the specialized forms of inquires to everyday world and also presenting claims raised in everyday world to the domain of specialized inquiries. So, it's because literary criticism and philosophy play a role in mediating between the two realms, that their language is rich in artistic, literary, argumentative, logical and generally diverse elements. Still in, both literary criticism and philosophy, poetic function is marginalized, and the major focus is on the critical analysis of texts and philosophical interrogation rather than something artistic and poetic (Habermas, 1987).

\section{Communicative Rationality Versus Disciplinary Power}

For Habermas, one thing common to both Foucault and Derrida, is their earlier appropriations of structuralism, as a general critique of modernity and its philosophy of the subject, and specifically as "a critic of the phenomenological-anthropological thought" (Habermas, 1987). Still, rather than approaching Nietzsche through Heidegger's destruction of the metaphysical tradition, Foucault appealed to Bataille-Nietzsche's critique of modernity as one that excludes certain groups and ideals like the mad and outcasts. Foucault further appropriated Bachelard's historical critique of the sciences, himself focusing on the social sciences. Habermas thinks that Foucault's insights from Levi-Strauss's Structuralism, Bataille's critique of 


\section{Fasil Merawi}

an excluding reason, and Bachelard's inquiries into the history of science, are witnessed in Foucault's first major work Madness and Civilization (1961).

Foucault's intentions in Madness and Civilization were that of going beyond the conventions, regularities and boundaries of Western thinking. By doing so, Foucault had an intention of appropriating what was forbidden, considered immoral, what's usually rejected, what's considered outdated and abnormal. Habermas sees, Bataille's dissolution of the homogenous with an experience that goes beyond the boundaries, being echoed in Foucault's critique of reason as that conventional boundary which excludes, and madness as a possibility of going beyond the conventions set by reason. Foucault admits the trouble of grasping the truth of madness and instead of trying to grasp its cognitive content, turns his attention to those moments in history where reason managed to establish its sole dominance and exclude other alternatives.

One of the ideas that Foucault developed as early as Madness and Civilization is that of forms of exclusion, supervision and disciplining. Foucault's ideas of a modern form of disciplining as established through schools, penitentiaries and so on, were developed, as Habermas sees it, where Foucault depicts how certain mental and medical institutions emerged trying to establish the truth of the hierarchically inferior division between reason and Madness. The difference is that, while in Madness and Civilization; Foucault sketches how the mad and generally Madness came to be excluded and neglected, in later works such as Discipline and Punishment and The history of Sexuality, he shows how modern reason in general resulted in a repressive power that employs different mechanisms to organize the whole of humanity into its domains, and in the process, crushes any other alternatives. As Foucault sees it, "the success of disciplinary power derives no doubt from the use of simple instruments: hierarchical observation, normalizing judgment, and their combination in a procedure that is specific to it, the examination" (Rabinow, 1984).

For Foucault, modern society constitutes a disciplinary system which operates by using observation as a way of controlling actions, establishing criteria for measurement and finally testing the conformity and subjugation of subjects. In some occasions Foucault characterized this creation of subjects to 'biopower'. Thus Foucault maintains "one would have
Sci. Technol. Arts Res. J., July-Sep 2012, 1(3): 75-87

to speak of bio-power to designate what brought life and its mechanisms into the realm of explicit calculations and made knowledge-power an agent of transformation of human life" (Foucault, 1990). Instead of an intersubjective arena where different claims to truth are entertained, modern society for Foucault is one that disciplines its subjects through different ways of accomplishing its goals. Foucault saw a direct relation between specific practices and the various human sciences. While the practices made available a 'self' to be experimented upon, the sciences endorsed the practices by creating a reservoir of scientific techniques, terms and solutions.

Thus, in Madness and Civilization, The Birth of the Clinic: all the way up to Discipline and Punish, Foucault witnesses how modern subjects have been treated by different practices, institutions and sciences as patients who aren't fit to participate in the normal, ordinary lives of modern societies. Thus, for Foucault, "in appearance, the disciplines constitute nothing more than an infralaw. They seem to extend the general forms defined by law to the infinitesimal level of individual lives; or they appear as methods of training that enable individuals to become integrated into these general demands" (Rabinow, 1984).

For Foucault, the move from treating the mad in 'confinements' to institutions by providing a clean, suitable, medical personnel and treatments paved the way for a better inspection, control and research over the mad. The institutions led to the emergence of various sciences on madness and the depiction of madness as a danger for our society and reason in general. Habermas is especially interested in looking at the extent to which Foucault's criticism of Western institutional and disciplinary rationality through an exposure of the genesis and development of the various sciences, in the form of archaeology and genealogy manages to avoid the paradox included in a total critique of reason which utilizes reason in the process. Since Foucault abandoned any recourse to rational argumentation and intersubjectivity, he appeals to archeology.

Foucault's analysis of modernity as a disciplinary power was facilitated through his methods, archeology and genealogy. Foucault elaborated on his Archaeological method which tries to identify the underlying epistemic structures within which the subject is constituted. In speaking of the Archeological method Foucault maintains "what I am doing is neither formalization nor an exegesis. But an archeology: that is to say, as its name indicates only too 


\section{Fasil Merawi}

obviously, the description of the record---the rules which at a given period and for a definite society defined" (Foucault, 1972). In Foucault's later works one finds Genealogy which views history as a directionless process which witnesses the rise and fall of diverse discursive formations. In trying to explore an alternative which goes beyond the metaphysical tradition Foucault argues "I have tried to get out from the philosophy of the subject through a genealogy of this subject, by studying the constitution of the subject across history which has led us up to the modern concept of the self." (Foucault, 1993) Still for Habermas; Foucault's approach is "presentistic, relativistic, cryptonormative". (1987) For Habermas Foucault's whole project is 'presentistic' since its starting point is that the various forms of knowledge are also immersed in power relationships. Furthermore upon a closer analysis Foucault's genealogy only turns out to be relative power/knowledge nexus. Finally Foucault's genealogy is not value free since it has sympathy for those who are abandoned and excluded by the dominant discourse.

\section{Interrogating the Modern}

The discussion so far was basically focused around two major areas. First of all I tried to introduce the essence of Habermas's discourse of modernity as communicative rationality. Secondly I tried to highlight some of the main points of debate in the modern/postmodern debate by elaborating on Habermas's discussion of Derrida and Foucault in The Philosophical Discourse of Modernity. In this section I will try to integrate my own insights into the debate through a discussion of the positive and negative aspects of Habermas's discourse of modernity and particularly his discussion of postmodernism.

1. In my opinion, the crucial aspect of communicative rationality that makes it strong when compared with the ideals developed throughout modernity, and the postmodern critics is that the concepts of responsibility and emancipation are highly developed in it. It is also a kind of rationality that could deal both a descriptive and emancipatory critical theory of modern societies. In Derrida's deconstruction an attempt is made to expose what's excluded in the binary operations and the search for origins in Western philosophical thought. But, as Habermas notes, the subject is lost in a process of meaning formation. We can see Derrida's attempt to deconstruct the texts of Western civilization, as an attempt to open up and reveal the history of exclusions. Still Derrida didn't propose any emancipatory, future ideal, except in asserting that meaning always
Sci. Technol. Arts Res. J., July-Sep 2012, 1(3): 75-87

comes. In Derrida's defense we can say that his later works like The specters of Marx haven't been taken into consideration in Habermas's discourse of modernity.

Foucault's archaeology and genealogy tried to identify thought patterns, specific practices, disciplines and institutions that determined a particular form of subjectivity in modernity. Foucault exposed and hence revealed the concealed practices, institutions, disciplinary techniques of Western society. But, as Habermas rightly observes, Foucault was not able to pose a normative ideal, and hence didn't find a space for responsibility. In addition, since the subject was not empowered in relation to a concept of emancipation, Foucault was not able to step out of power/knowledge nexuses.

When we come to Habermas's communicative rationality and discourse of modernity we can raise the following points. First of all, we are responsible for history, since we are active agents and participate in intersubjective process that empowers us. We have control over our destinies insofar as we are capable of reflecting on the background we inhabit; being able to reflect on our social structures. Secondly, there is a space for discussing modern society's problems like anomie, meaninglessness, the holocaust and so on, by appealing to everyday language. Everyday language and communicative rationality have provided a space for discussing modern society's problems resulting from the continuing rift between the everyday world and value spheres, and also the colonization of the life world. Thirdly, there is a space in communicative rationality for envisioning emancipatory ideals. This is through strengthening everyday communicative action, strengthening the value spheres, empowering the institutions in which the positive universal ideals of modernity are concretized and strengthening the public spheres. Thus, Habermas has found a space for a communicative rationality and a critical social theory of modern societies which is both diagnostic and could also pose emancipatory ideals.

2.Still, Habermas's discourse of modernity fails to fully address asymmetrical power relations. Habermas tried to explain modern society's problems as resulting from the 'colonization of the life world' or the process through which the communicative rationality of everyday world is threatened by the instrumental one of the 
Fasil Merawi

system. Amongst the major solutions Habermas proposes include, strengthening the life world and everyday communicative action to counter systemic instrumental rationality and strengthening autonomous public spheres. These are spheres freed of ideological interests and where positive extracts from everyday communication are discussed. Generally we can raise three points in relation to the extent to which Habermas's theory of modernity addresses the concrete and material aspect of life. First, Habermas failed to see how asymmetric power relations are embedded in the life world. The materials to be reflected, the common sense knowledge we have of the world and the abiding moral rules that form a sense of belongingness to a community represent the interests of the dominant groups in our societies. Accordingly, biased structures and meanings pass down into every day communication. Further the horizon of everyday communication is limited since even though the life world is continually being reflected upon, still the dominant agendas are those of the oppressors.

As Enrique Dussel remarks what the 'interpellation' the presenting of the claims of the oppressed to the exploiter, introduces is an exposition of unjust, asymmetrical relations in day to day life, and their transformation in a praxis that goes to the heart of the dominant presuppositions. Dussel remarks that, "[t]here is no liberation without rationality, but there is no critical rationality without accepting the interpellation of the excluded, or this would inadvertently be only the rationality of domination" (Dussel, 1996). In his article The architectonic of the ethics of liberation on material ethics and formal moralities, Dussel tries to come up with an argumentative ethic based in concrete, material economic relations. This is supposed to surpass 'formal ethics' that only focuses on the universal argumentative nature of the ethical dimension on one hand, and materialistic versions of ethics that only focus on limited material, economic relations. What Dussel proposes in turn is a realization of the two. Thus he remarks, "The goal is the elaboration of an ethics that is able to incorporate the material aspects of goods and the formal dimension of ethical validity and consesuability; every morality is the formal application of some substantive good" (Dussel, 1997). Thus, Habermas's communicative rationality fails to fully address the corrupted nature of everyday communication resulting from power relations.
Sci. Technol. Arts Res. J., July-Sep 2012, 1(3): 75-87

Secondly, Habermas's explanations of modern society's problems are focused on the loss of meaning, since the explanation derives from systems intrusion into the meaning giving structure of the lifeworld. This prevented Habermas from providing a sufficient account of things like slavery and colonialism which signify primarily conflicts in the material aspect of life. Thirdly, in his account of "autonomous public spheres," Habermas failed to realize that the same problems that haunted his, Structural transformation of the public sphere i.e. asymmetric relations resulting from the superiority of the wealthy and educated, also exist in today's public spheres. Usually, the agendas raised in such spheres are backed by the funding of institutions that impose their own interests and what's discussed is usually what's considered as important by intellectuals. As Dussel shows in his The underside of modernity, hierarchical relations are found in speech acts. To this extent, Dussel gives a special attention to the claim of the oppressed. The utterance of the oppressed has a power of illuminating asymmetrical power relations. Dussel refers to the ideal symmetrical communicative arena as an ideal communicative community' in contrast to the 'empirical' one. Here, there are power relations and some voices are superior to others. Dussel also emphasized the fact that beyond communication one finds material, economic relations through which humans try to reproduce their life materially. Everyday communication is an exemplar of material relations. As Asger Sorensen puts it, what Dussel's transmodern approach to meaning and validity demonstrates is that; "practical philosophy must never forget the body as the material foundation of the consciousness. It is with the body that we feel pleasure but it is also with the body we feel pain" (Sorensen, 2009). Thus, Habermas's discourse of the modern only focuses on what Dussel calls the 'ideal communicative community'.

3. Habermas's discourse of modernity is Eurocentric in failing to fully deconstruct the Eurocentric tendencies of the Western philosophical tradition. For Habermas, following Weber and Hegel, one could argue that modernity took shape by a universal process of secularization and rationalization, and through historical movements like the Reformation the Enlightenment, and French revolution. This ignores the fact that, amongst other things, the age of discoveries for Europe was not only a search for material inputs and economic superiority, but also the construction of 


\section{Fasil Merawi}

Europe's other, an inferior other, against whom Europe could consolidate itself. Habermas should have focused on how the French revolution only meant liberation for male whites, and that outside of Europe, the same exploitative relations dismantled by the revolution in Europe, were, still continuing. Habermas also failed in identifying what Dussel calls "the fallacy of developmentalism". (Dussel, 1993,67-68) Developed in the modern period, and still persisting today, Europe presents itself as the ideal model, in the developmental policies it formulates. Further, Habermas also did not give a sufficient account of the contribution of non-Western civilizations to modern Europe, how scientific, religious and moral insights were being transferred through commerce starting from ancient Greece. Instead, he simply forwards the secular tradition of modern Europe as the universal model, under the guise of an open communication carried out between equal partners.

Following the arguments of Eze, one could identify two truths about modernity that were not addressed by Habermas. First, Eze rightly pointed out that colonialism and modernity cannot be separated. Modern Europe used the colonies as a way of extracting material inputs and strengthening its greatest achievements in science, morality, the state and arts. Thus Eze maintains "the single most important factor that drives the field and the contemporary practice of African/a philosophy has to do with the brutal encounter of the African world with European modernity-an encounter optimized in the colonial phenomena" (1997) Also, it was the ideas that were found at the heart of modern Europe understanding of itself and best described in the giant philosophers like Hegel and Kant that provided the justifications for colonialism and imperialism. Thus the;

significant aspects of the philosophies produced by Hume, Kant, Hegel, and Marx have been shown to originate in, and to be intelligible only when understood as an organic development within larger socio historical contexts of European colonialism and the ethnocentristic idea: Europe is the model of humanity, culture, and history in itself. (Eze, 1997)

\section{CONCLUSION}

For Habermas, communicative rationality provides the strongest alternative compared to the ideals provided by modernization, modernism
Sci. Technol. Arts Res. J., July-Sep 2012, 1(3): 75-87

and postmodernism.. Elaborated in terms of Weber's theory of rationalization and Hegel's attempt to interrogate the 'present', Habermas's modernity provides a secularist approach to modern societies. Habermas's discourse of modernity constitutes a response to the postmodernist movement in general and the poststructuralism of Derrida and Foucault in particular. From Habermas's point of view, postmodernism radically deconstructs modernity and tries to provide a new ideal in the heterogeneous, the non rational, and generally in that which steps outside of the modern. Thus, Habermas defended communicative rationality against Derrida's deconstruction and Foucault's theory of disciplinary power, by arguing that they fail to recognize the communicative processes of modern societies under the employment of ordinary speech acts. Habermas's modernity has a negative aspect of failing to fully unmask asymmetrical power relations embedded in the history of modernity and also failing to unconceal the eurocentrism of modernity. On the other side, Habermas's discourse of modernity should be acknowledged for developing an account of rationality where the concepts of responsibility and emancipation are developed and also offers a critical theory of society that analyzes modern society's problems and also proposes emancipatory ideals.

\section{REFERENCES}

Anderson, Walter Truett (1995). The Truth about the truth, de-Confusing and re-instructing the Postmodern World. Jeremy P. Tarcher Putnam Penguin, USA.

Benhabib, Seyla (1997). Habermas and the Unfinished Project of Modernity. The MIT press.USA.

Best, Steven .(2005). The Politics of Historical Vision. Marx, Foucault, and Habermas, Guilford U.S.A.

Cahoone, Lawrence. (2003) From Modernism to Postmodernism, an Anthology. Blackwell Publishing, U.S.A.

Derrida., Jacques. (1997). Of Grammatology Trans. Gayatri hakravorty Spivak: John Hopkins University Press. U.S.A.

Derrida., Jacques, (2005). Writing and Difference Trans. Alan Bass. Routledge.U.S.A.

Dussel, Enrique (1993) Eurocentrism and Modernity, Introduction to the Frankfurt lectures. Duke university Press 20(3): 65-76.

Dussel., Enrique. (1996). The Underside of Modernity: Apel, Ricoeur, Rorty, Taylor and the Philosophy of Liberation ed. and Trans. Eduardo Mendietta. Humanities Press U.S.A. 
Fasil Merawi

Dussel, Enrique (1997) The Architectonic of the Ethics of Liberation on Material Ethics and Formal Moralities. Sage Publications 23( 3): 1-35.

Eze, Emmanuel Chukwudi (1997). Postcolonial African Philosophy, a Critical Reader, Blackwell Publishers, USA.

Finlayson., James Gordon. (2005). Habermas: A very Short Introduction.Oxford University Press. U.S.A.

Foucault., Michel. (1972). History, Discourse and Discontinuity" Trans Anthony M. Nazzaro Salmagundi. No. 20. Pp. 225-248.

Foucault., Michel. (1990). The History of Sexuality volume 1; an introduction. Trans. Robert Hurley vintage books. U.S.A:

Foucault, Michel. (1993). About the Beginning of the Hermeneutics of the Self: Two Lectures at Dartmouth. Sage Publications. 21: 198-227.

Habermas., Jürgen. (1984). The Theory of Communicative Action, Volume One, Reason and the Rationalization of society. Trans-Thomas McCarthy. Beacon Press. U.S.A.

Habermas, Jürgen (1987). The Philosophical Discourse of Modernity, Twelve Lectures, Massachusetts Institute of Technology. Trans Frederick Lawrence, U.S.A.

Matustik, Martin J. (1989) Habermas on Communicative Reason and Performative Contradiction. New German Critique 47:143-172.

Owen David, S. (2002). Between Reason and History: Habermas and the idea of progress. State University of New York Press, U.S.A.

Rabinow and Paul, (1984). The Foucault reader. Random House inc, USA.

Rorty, Richard-(1984), Habermas and Lyotard on Postmodernity. Praxis International. Vol 4.

Ryan, Michael. (1982) Marxism and Deconstruction, a critical Articulation. The John Hopkins University Press, U.S.A.

Sorensen, Asger, (2009) Enrique Dussel A Critique of Ideology from the South, Roskike University 2(2): 84-101.
Sci. Technol. Arts Res. J., July-Sep 2012, 1(3): 75-87 